\author{
BULETINUL INSTITUTULUI POLITEHNIC DIN IAŞI \\ Publicat de \\ Universitatea Tehnică „Gheorghe Asachi” din Iaşi \\ Volumul 67 (71), Numărul 1, 2021 \\ Secţia \\ CONSTRUCTII DE MAȘINI \\ DOI:10.2478/bipcm-2021-0004 \\ sciendo
}

\title{
TAGUCHI'S METHOD IMPLEMENTED FOR WIND BLADE DESIGN
}

BY

\section{BRUNO RĂDULESCU* ${ }^{*}$ and MARA-CRISTINA RĂDULESCU}

\author{
"Gheorghe Asachi" Technical University of Iaşi, \\ Faculty of Machine Manufacturing and Industrial Management
}

Received: January 18, 2021

Accepted for publication: March 11, 2021

\begin{abstract}
This paper presents the Taguchi method implemented for analyzing different types of wind blade structure.

Keywords: Orthogonal experiment; wind turbine blade design; Taguchis's method; displacement.
\end{abstract}

\section{Introduction}

The fluctuations of the industrial production determine the introduction of some measures that would allow the companies to be able to react in the shortest time to new challenges and also to reduce the costs (Antony et al., 2013). This reaction has two components. First component is outsourcing of some processes on the emerging market and the second component corresponds to the necessary tools that have to be created to accelerate the processes involved.

The outsourcing of processes involves not only moving those processes on emerging markets, but also shifting the energy consumption that was allocated for those processes to these emerging markets.

*Corresponding author; e-mail: mmanaila@yahoo.com

(C) 2021 Bruno Rădulescu et al.

This is an open access article licensed under the Creative Commons Attribution-NonCommercialNoDerivatives 4.0 International License (CC BY-NC-ND 4.0). 
This approach does not involve only one field of activity, but a synergy of activities that have never collaborated before.

This transfer of outsourcing of processes also means changing the energy structure of these emerging markets.

For this reason, using a free and regenerable way of energy becomes a must.

\section{Employing Experimental Plans for Wind Energy Generation}

For thousands of years wind energy was used in different ways to help the communities of peoples. This was also a reason for the members of those communities to meet each other and to socialize.

Today with a reduced fossil fuel stock and a large dependencies of fossil fuel, the need of employing new regenerative energy solutions, had increased during the last few decades.

The energy resources are undoubtedly insufficient. The potential for sustainable exploitation of an inexhaustible resource depends only on the storage capacity of such a resource.

Experimental plans optimization, is a strategy to ensure the performance of the system and to satisfy the sensitivity of it, varying the established parameters by the designer, that may impact the final product.

An experiment plan containing parameters and their interactions is used to reduce the number of vital experiments, thus eliminating the independent testing of parameters, as well as the lack of approach of the interactions between the parameters considered during the experiment, to study the comportment of the whole system.

The accuracy of the observations is not affected.

\section{Optimizing the Experimental Plans}

Producing is just a fragment of the equation. Also quality of what we have to produce, costs of what we have to produce and delays of what we have to produce (Gupta, 2015) has to be involve in this equation.

An experimental plan means like we already presented, to create a series of tests organized in advance to determine, with a minimum of costs and a maximum accuracy, the possible influences of different parameters, in order to optimize the performance of the studied system (Fig. 1). 


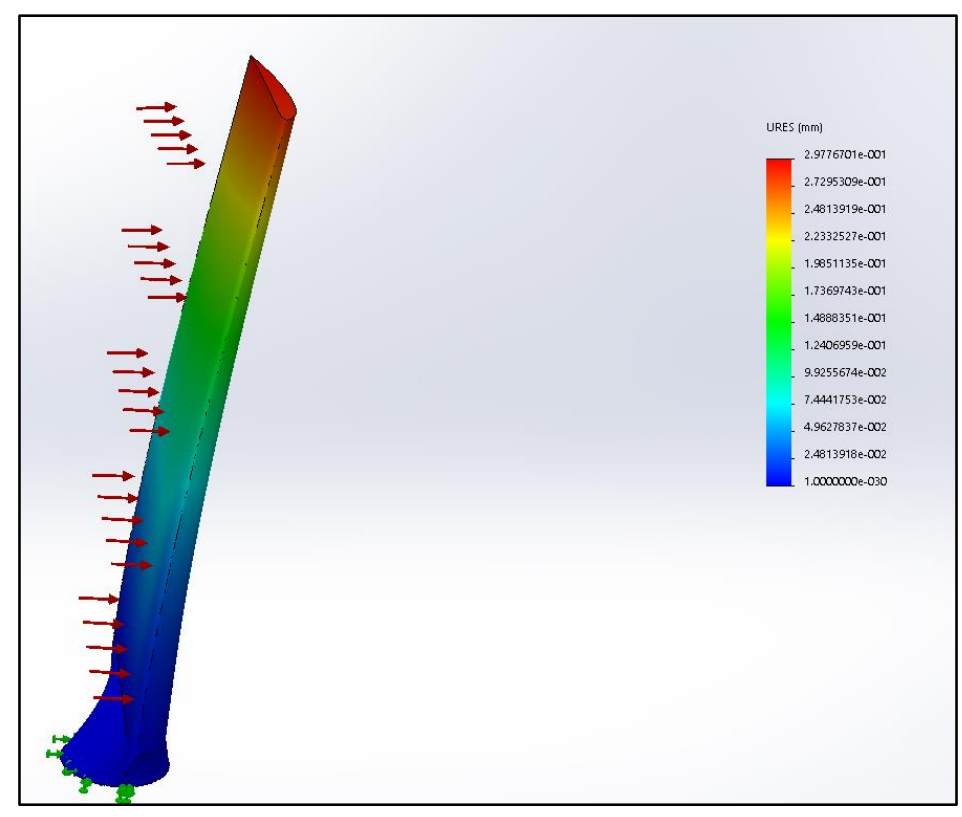

Fig. 1 - Displacement results for a shell wind blade.

The main roll of this experimental plan is also to reduce the costs of the experiment, with the same results, regarding the study of the concerned system. To apply an experience plan, you need to go through the following steps:

a) Formulation of the problem, which involves the following sub-steps:

1 - Defining the problem;

2 - Determining the objective;

3 - Formation of a working group;

4 - Review of constraints;

5 - Defining the answer;

6 - Choice of parameters;

7 - Establishing the levels of each factor;

8 - Identifying interactions.

b) Building the experience plan;

c) Carrying out tests and measuring results;

d) Processing the results and calculating the effects of the tested parameters;

e) Choosing the configuration of the levels of the different parameters tested, in order to optimize the quality criteria;

f) Carry out a validation test to ensure that the intended results are achieved. 

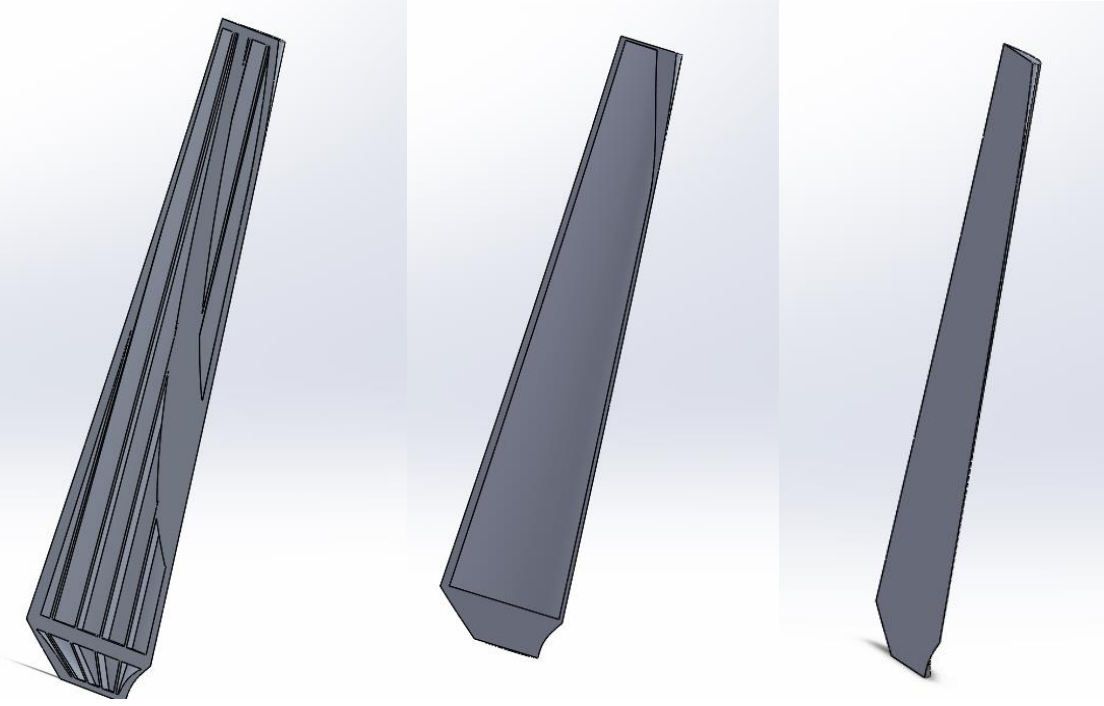

Fig. 2 - Sections views.

The experiment plan was designed in order to establish the influence of technological parameters, such as the pressure, structure, mesh elements length, density and mesh elements quantity included in a circle. The established experiment type is the fractional orthogonal factorial, type $3 \mathrm{n}$ (for 5 input parameters, in this case we have $35=243$ experiences).

Based on the relationships in the literature, the L27 fractional plan was selected, which consists in performing a minimum and sufficient number of 27 experiments. The levels of variation were set in such a way as to satisfy the complexity of the approach and the existing technical possibilities (Fig. 1).

The theoretical model has the following relation (1) (Rădulescu and Rădulescu, 2020):

$Y \approx M+P+S+\operatorname{Mesh}_{D}+\operatorname{Mesh}_{P}+D M+P-D M+S-M_{e s h_{D}}+P-M_{e s h}$

The displacement that can affect the presented part, are done by applying a pressure on the blade face (Rădulescu et al., 2006; Rădulescu and Rădulescu, 2020).

As we presented in (Rădulescu and Rădulescu, 2020), the 5 parameters are employed at 3 levels.

The displacement experimental research on a wind blade is done and is presented in (Rădulescu et al., 2020) employing the Taguchi's orthogonal method (Taguchi, 1987), without deforming it in the plastic domain. 


\section{Average Response for Each Parameters Levels}

The average values for the three levels of the five parameters as calculated using the relation (2):

$$
\bar{Y}_{i}=\frac{1}{9} \sum_{i=1}^{9} Y_{i}
$$

Starting with those averages parameters levels values we calculate the averages displacements.

The results of average displacements are presented in the following table (Table 1).

Table 1

The Average Values for Displacements

\begin{tabular}{|c|c|c|c|c|c||}
\hline $\begin{array}{c}\text { Parameters } \\
\text { Level }\end{array}$ & $\bar{P}$ & $\overline{\mathrm{S}}$ & $\overline{\text { Mesh_D }}$ & $\overline{\text { Mesh_P }}$ & $\overline{D M}$ \\
\hline \hline Level 1 & 0.2635 & 0.5562 & 1.3166 & 1.3261 & 1.5057 \\
\hline Level 2 & 1.0627 & 1.1162 & 1.2501 & 1.1821 & 1.156 \\
\hline Level 3 & 2.3934 & 2.0472 & 1.1529 & 1.2113 & 1.0579 \\
\hline
\end{tabular}

\section{Overall Average of the Tests Set for Displacements}

The overall average of the set of tests regarding the displacements of the processed materials is calculated using the relation (3) presented below:

$$
M_{D}=\frac{1}{27} \sum_{i=1}^{27} Y_{i}=1.2399
$$

\section{Calculation of the Average Effects of the Parameters Used for Displacements}

The average effects of the parameters are calculated using the relation (4):

$$
E Y_{i}=\bar{Y}_{\iota}-M_{D}
$$

where $i$ represents the level for which the calculation is performed (respectively 1,2 or 3), and is the average response for the three levels of the 5 parameters. Applying the previous relation, we obtain (5):

$$
E P_{1}=\overline{P_{1}}-M_{D}=0.2635-1.2399=-0.9764
$$

The results are centralized in the table below (Table 2). 
Table 2

Average Effects

\begin{tabular}{|c|c|c|c|c|c||}
\hline $\begin{array}{c}\text { Average effects } \\
\text { Level }\end{array}$ & EP & ES & E Mesh_D & E Mesh_P & EDM \\
\hline \hline Level 1 & -0.9763 & -0.6837 & 0.0767 & 0.0863 & 0.2658 \\
\hline Level 2 & -0.1772 & -0.1237 & 0.0102 & -0.0577 & -0.0839 \\
\hline Level 3 & 1.1535 & 0.8073 & -0.0869 & -0.0285 & -0.1820 \\
\hline
\end{tabular}

\section{Conclusions}

The need to study the process of deformation of wind turbine blades, occurs due to the use of this type of energy on an increasing scale, due to the ease with which this energy is generated, but also the complexity of the phenomena associated with it.

\section{REFERENCES}

Antony J., Warwood S., Fernandes D., Rowlands H., Process Optimization Using Taguchi Methods of Experimental Design. Work Study, Asian Journal of Scientific Research, 6, 1, 27-37 (2013).

Gupta A.K., Efficient Wind Energy Conversion: Evolution to Modern Design, ASME Journal of Energy Resources and Technology (2015).

Rădulescu M., Braha V., Rădulescu B., The Methodologies for Planned Experiments, Bul. Inst. Polit. Iaşi, XLVIII (LII), 5B, 787-789 (2006).

Rădulescu M., Rădulescu B., Ortogonal Experimental Plans for a Wind Turbine Blade Design, Bul. Inst. Polit. Iaşi, s. Construcţii de Maşini, 66 (70), 1, 1-10 (2020).

Taguchi G., System of Experimental Design, Unipub/Kraus International Publication, S.U.A., 1987.

\section{IMPLEMENTAREA METODEI TAGUCHI PENTRU PROIECTAREA UNEI PALETE DE TURBINĂ EOLIANĂ}

(Rezumat)

Această lucrare prezintă implementarea metodei Taguchi în proiectarea unei palete de turbină eoliană.

Sunt cercetaţi parametrii ce influentează proiectarea unei astfel de palete, iar valorile, care influenţează proiectarea unei astfel de palete, sunt analizate utilizând programe diferite ce au ca scop reducerea timpului de proiectare, dar şi reducerea costurilor de productie. 